\title{
ADENOVIRUS-MEDIATED GENE TRANSFER OF HUMAN INTERLEUKIN 10 AMELIORATES REPERFUSION INJURY OF RAT LUNG ISOGRAFTS
}

Hideki Itano, MD

Wanjiang Zhang, MD ${ }^{\mathrm{a}}$

Jon H. Ritter, MD

Timothy J. McCarthy, $\mathrm{PhD}^{\mathrm{c}}$

T. Mohanakumar, $\mathrm{PhD}^{\mathrm{a}}$

G. Alexander Patterson, MD $^{\mathrm{a}}$
Objective: The objective of this study was to examine the feasibility of human interleukin 10 gene transfer into rat lung isografts and to investigate the effect of gene transfer on subsequent ischemia-reperfusion injury.

Methods: Male F344 rats were divided into 4 groups and underwent left lung isotransplantation. Twenty-four hours before harvest, $5 \times 10 \mathrm{E} 9 \mathrm{pfu}$ (group I, $\mathrm{n}=6$ ) or $1 \times 10 \mathrm{E} 10 \mathrm{pfu}$ (group II, $\mathrm{n}=7$ ) of AdRSVhIL-10 was intravenously administered to donor rats. In group I-C $(n=6)$ and group II-C $(n=6)$, serving as controls, $5 \times 10 \mathrm{E} 9$ pfu and $1 \times 10 \mathrm{E} 10$ pfu of AdCMVLacZ were administered, respectively. Grafts were preserved for 18 hours at $4^{\circ} \mathrm{C}$ before implantation and assessed 24 hours after reperfusion. Transgene expression of human interleukin 10 was assessed by both reverse transcriptase-polymerase chain reaction and immunohistochemistry. Graft inducible nitric oxide synthase, tumor necrosis factor $\alpha$, intercellular adhesion molecule-1, growth-regulated gene product/cytokine-induced neutrophil chemoattractant-1, and monocyte chemotactic protein-1 mRNA expression were assessed by reverse transcriptase-polymerase chain reaction. Isograft gas exchange, exhaled nitric oxide, and myeloperoxidase activity were also analyzed.

Results: Dose-dependent transgene expression was detected by reverse transcriptase-polymerase chain reaction and immunohistochemistry. Arterial $\mathrm{Po}_{2}$ in groups I $(164.72 \pm 85.3 \mathrm{~mm} \mathrm{Hg})$ and II $(153.19 \pm 113 \mathrm{~mm} \mathrm{Hg})$ was significantly higher than in groups I-C $(82.37 \pm 19.1 \mathrm{~mm} \mathrm{Hg})$ and II-C $(77.95 \pm 33.4 \mathrm{~mm} \mathrm{Hg})(P=.022$ and $P=.031$, respectively $)$. Arterial $\mathrm{PCO}_{2}$ in group I $(33.40 \pm 6.80 \mathrm{~mm} \mathrm{Hg})$ was significantly lower than in group I-C $(51.23 \pm 11.9 \mathrm{~mm} \mathrm{Hg})(P=.0096)$. Myeloperoxidase activity in group II $\left(0.083 \pm 0.031 \Delta \mathrm{OD} \cdot \mathrm{min}^{-1} \cdot \mathrm{mg}^{-1}\right)$ was significantly lower than in group II$\mathrm{C}\left(0.117 \pm 0.028 \Delta \mathrm{OD} \cdot \mathrm{min}^{-1} \cdot \mathrm{mg}^{-1}\right)(P=.044)$. The inducible nitric oxide synthase mRNA expression in group II $(0.627 \pm 0.28)$ was significantly lower than in group II-C $(1.125 \pm 0.63)(P=.039)$.

Conclusion: Adenovirus-mediated human interleukin 10 gene transfer in vivo into lung isografts ameliorates subsequent ischemia-reperfusion injury. This results in improved graft gas exchange, reduced neutrophil sequestration, and down-regulation of graft inducible nitric oxide synthase mRNA expression. (J Thorac Cardiovasc Surg 2000;120:947-56)
From the Division of Cardiothoracic Surgery, ${ }^{a}$ Departments of Pathology ${ }^{\mathrm{b}}$ and Radiology, ${ }^{\mathrm{c}}$ Washington University School of Medicine, St Louis, Mo.

This work was supported by the National Institutes of Health grants RO1 HL 41281 (G.A.P.), HL 56643 (T.M.), and the Whitaker Foundation (T.J.M.). The nitric oxide analyzer was purchased through a grant from the Whitaker Foundation (T.J.M.). H.I. was supported by the Okayama University Medical School.

Read at the Eightieth Annual Meeting of The American Association for Thoracic Surgery, Toronto, Ontario, Canada, April 30-May 3, 2000.
Received for publication May 4, 2000; accepted for publication June $6,2000$.

Address for reprints: G. Alexander Patterson, MD, 3108 Queeny Tower, One Barnes-Jewish Hospital Plaza, St Louis, MO 63110 (E-mail: Kellym@msnotes.wustl.edu).

Copyright (ㄷ 2000 by The American Association for Thoracic Surgery

$0022-5223 / 2000 \$ 12.00+0 \quad \mathbf{1 2 / 6 / 1 0 9 2 4 0}$

doi:10.1067/mtc. 2000.109240 
$\mathrm{L}$ ung transplantation has evolved into an effective therapeutic option in the management of patients with end-stage pulmonary diseases. ${ }^{1}$ However, early acute graft dysfunction still remains a serious impediment to the clinical success of lung transplantation, accounting for significant postoperative morbidity and mortality. Temporary introduction of genes to organs that results in transient gene expression and production of a functional gene product may be an effective strategy to decrease such ischemia-reperfusion (I/R) injury. In vivo gene delivery into donor organs before harvest may offer a specific method for achieving graft-targeted, sustained, endogenous production of therapeutic gene products, while at the same time minimizing possible unwanted exposure of nontargeted organs. Gene transfer of anti-inflammatory cytokine genes to the graft may be a viable local anti-inflammatory strategy, by impairing inflammatory cytokine cascade or reducing accumulation of neutrophils into lung grafts after reperfusion oxidant stress.

Interleukin 10 (IL-10) is mainly produced by macrophages and helper $\mathrm{T}$ lymphocyte 2 cells. It significantly modulates expression of cytokines, soluble mediators, and cell surface molecules on cells of myeloid origin. IL-10 strongly inhibits the production of IL-1, IL-6, IL-8, IL-10 itself, IL-12, granulocytemacrophage colony-stimulating factor, tumor necrosis factor $\alpha$ (TNF- $\alpha$ ), and various chemokines by activated monocyte/macrophages. ${ }^{2,3}$ IL-10 also enhances production of IL-1 receptor antagonist ${ }^{2}$ and soluble p55 and p75 TNF receptor. ${ }^{4}$ IL-10 also inhibits the expression of intercellular adhesion molecule-1 (ICAM-1) and reduces the generation of superoxide anion $\left(\mathrm{O}_{2}^{-}\right)^{5}$ and nitric oxide (NO). ${ }^{6}$ Thus, IL-10 induces a shift from production of pro-inflammatory to anti-inflammatory mediators. Due to these effects, we postulated that IL-10 may be useful in the treatment or prevention of $\mathrm{I} / \mathrm{R}$ injury. In the current study, we examined the influence of human IL-10 (hIL-10) gene overexpression in lung isografts on subsequent acute graft dysfunction after orthotopic transplantation.

\section{Material and methods}

Adenoviral vectors. The replication-deficient recombinant adenovirus AdRSVhIL-10 was obtained from the Gene Therapy Vector Core, University of Iowa, College of Medicine (Iowa City, Iowa). This recombinant adenovirus expressing hIL-10 was generated by homologous recombination between pAdRSVhIL-10 and human adenovirus serotype 5 derivative d1309, by means of standard methods, ${ }^{7}$ and the bioactivity of this recombinant adenovirus was confirmed by in vitro bioassay, as previously described. ${ }^{8}$ The recombinant adenovirus Ad5CMVLacZ expresses the gene for Escherichia coli $\beta$-galactosidase and contains the human cytomegalovirus gene promoter/enhancer. Adenovirus amplification was propagated in 293 cells several times to obtain high-titer stocks, as determined by the plaque assay (Gene Therapy Center Vector Core Facility, the University of North Carolina, Chapel Hill, NC). Viral stocks of $1.60-3.75 \times$ $10 \mathrm{E} 11$ plaque-forming units per milliliter $(\mathrm{pfu} / \mathrm{mL})$ were kept at $-80^{\circ} \mathrm{C}$, thawed, and diluted in $1 \mathrm{~mL}$ saline solution immediately before intravenous administration to donors.

Animals. Male inbred F344 rats, weighing 250 to $320 \mathrm{~g}$, were obtained from Harlan Sprague-Dawley Inc (Indianapolis, Ind). All animal procedures were approved by the Animal Study Committee of Washington University. Animals received humane care in compliance with the "Guide for the Care and Use of Laboratory Animals" prepared by the Institute of Laboratory Animal Resources, National Research Council, and published by the National Academy Press, revised 1996.

Study design, gene transfer, and transplantation. Male F344 rats were divided into 4 groups and underwent left lung isotransplantation. Twenty-four hours before harvest, $5 \times$ 10E9 pfu (group I, $\mathrm{n}=6$ ) or $1 \times 10 \mathrm{E} 10 \mathrm{pfu}$ (group II, $\mathrm{n}=7$ ) of AdRSVhIL-10 was intravenously administered to donor rats. In groups I-C $(n=6)$ and II-C $(n=6)$, serving as control groups, $5 \times 10 \mathrm{E} 9$ pfu or $1 \times 10 \mathrm{E} 10$ pfu of AdCMVLacZ was administered, respectively. The adenovirus diluted in $1 \mathrm{~mL}$ of saline solution was injected into the left internal jugular vein of the anesthetized donors in the supine position for $30 \mathrm{sec}-$ onds, and the donor rats were allowed to recover from anesthesia. Twenty-four hours after virus injection, donors were put to death. Donor lungs were flushed via the main pulmonary arteries with $20 \mathrm{~mL}$ of cold $\left(4^{\circ} \mathrm{C}\right)$ low-potassiumdextran-1\% glucose solution after systemic heparinization. Heart-lung blocks were immediately excised en bloc and stored in low-potassium-dextran-1\% glucose solution at $4{ }^{\circ} \mathrm{C}$ for 18 hours. Left lung isografts were then orthotopically transplanted by means of a modification of the previously described "cuff technique.",

Assessment. Recipient animals underwent median sternotomy 24 hours after reperfusion. After crossclamping of the right main bronchus and pulmonary artery, isografts were ventilated with $100 \%$ oxygen, $1.5 \mathrm{~mL}$ tidal volume, rate 100 breaths/min. Peak airway pressures were measured, and exhaled gas was collected for 3 minutes. After 5 minutes of graft ventilation, arterial blood samples were obtained for blood gas analysis. Recipients were then killed and left lung isografts were immediately flushed with $20 \mathrm{~mL}$ of cold saline solution. The lower half of the lung graft was frozen in liquid nitrogen and stored at $-80^{\circ} \mathrm{C}$ for reverse transcriptase-polymerase chain reaction (RT-PCR) and myeloperoxidase assessment. The upper half of the graft was fixed with Histochoice fixative (AMRESCO, Solon, Ohio) flushed through the trachea with $20 \mathrm{~cm} \mathrm{H}_{2} \mathrm{O}$ for immunohistochemistry.

RNA isolation and cDNA synthesis. Total lung RNA was prepared by guanidine isothiocyanate extraction with RNeasy Mini (QIAGEN Inc, Valencia, Calif), according to the manufacturer's instructions. Extracted RNA was quantified by a 
spectrophotometer (Spectronic Genesys 5; Spectronic Instruments, Inc, Rochester, NY). Each $1 \mu \mathrm{g}$ of extracted RNA sample was reverse-transcribed at room temperature for 10 minutes, $42^{\circ} \mathrm{C}$ for 15 minutes, $99^{\circ} \mathrm{C}$ for 5 minutes, and $5^{\circ} \mathrm{C}$ for 5 minutes in a total of $20 \mu \mathrm{L}$ reaction mixture: $\mathrm{MgCl}_{2}, 5 \mathrm{mmol} / \mathrm{L} ; \mathrm{KCl}, 50 \mathrm{mmol} / \mathrm{L}$; Tris- $\mathrm{HCl}, 10 \mathrm{mmol} / \mathrm{L}$; $\mathrm{pH} 8.3$; and $1 \mathrm{mmol} / \mathrm{L}$ of each deoxynucleotide-triphosphate, $1 \mu \mathrm{L}$ RNase inhibitor, $2.5 \mathrm{U} / \mu \mathrm{L}$ cloned murine leukemia virus reverse transcriptase, and $2.5 \mu \mathrm{mol} / \mathrm{L}$ oligo $\mathrm{d}(\mathrm{T})^{10}$ (Perkin Elmer, Foster City, Calif).

Semiquantitative PCR. To confirm hIL-10 transfection and to investigate its influence on isograft cytokine alteration, we performed semiquantitative RT-PCR for transgene hIL-10 and several endogenous cytokines. Normal left lung samples of F344 rats (NL, n=6) were also assayed in the same way as the other groups for comparison. Reverse-transcribed cDNA was amplified by PCR with 0.02- to 0.03$\mathrm{U} / \mu \mathrm{L}$ HotStarTaq Polymerase (QIAGEN Inc, Valencia, Calif) on a Mastercycler gradient (Eppendorf Scientific, Hamburg, Germany) in a $22-\mu \mathrm{L}$ reaction: $2.0 \mu \mathrm{L}$ of reverse transcriptase product, $1.0 \mathrm{mmol} / \mathrm{L}$ of $\mathrm{MgCl}_{2}, 200 \mu \mathrm{mol} / \mathrm{L}$ of each deoxynucleotide-triphosphate, and 0.3 to $0.5 \mu \mathrm{mol} / \mathrm{L}$ of each primer, PCR buffer (QIAGEN Inc, Valencia, Calif) including $\mathrm{KCl}$, Tris- $\mathrm{HCl},\left(\mathrm{NH}_{4}\right)_{2} \mathrm{SO}_{4}$, after the first step of $95^{\circ} \mathrm{C}$ for 17 minutes, 25 to 35 cycles of $95^{\circ} \mathrm{C}$ for 30 seconds, $58^{\circ} \mathrm{C}$ (annealing temperature varying for different primers) for 30 seconds, and $72^{\circ} \mathrm{C}$ for 1 minute, followed by a final incubation at $72^{\circ} \mathrm{C}$ for 10 minutes. The sequence of primer pairs was designed for glyceraldehyde-3-phosphate dehydrogenase (GA3PDH) (sense: 5'-CATGACCACAGTCCATGCCATCAC3'; antisense: 5'-CATGTAGGCCATGAGGTCCACCAC-3'; 472 bp), hIL-10 (sense: 5'-CGCGGATCC CATGCACAGCT CAGCACTG-3'; antisense: 5'-CGCGGATCCGCCACCCTGATGTCTCAGT-3'; 570 bp), iNOS (sense: 5'-GCCTCCCTCTGGAAAGA-3'; antisense: 5'TCCATGCAGACAACCTT-3'; 500 bp), TNF- $\alpha$ (sense: 5'CTCAAAACTCGAGTGACAAGC-3'; antisense: 5'CCGTGATGTCTAAGTACTTGG-3’; 420 bp), growthregulated gene product/cytokine-induced neutrophil chemoattractant-1 (GRO/CINC-1) (sense: 5'-ACTCCAACAGAGCACCATGG-3'; antisense: 5'-TTGAGTGTGGCTATGACTTCG-3’; 222 bp), monocyte chemotactic protein-1 (sense: 5'-ATGCAGGTCTCTGTCACG-3'; antisense: 5'-CTAGTTCTCTGTCATACT-3'; 447 bp), and ICAM-1 (sense: 5'-TTCCTGCCTCGGGGTGGATCCG-3'; antisense: 5'-AGAGCTGTGTCCGCGGTGCTCC-3'; 331 bp). PCR cycles and annealing temperature were calibrated for each primer pair. The GA3PDH bands were used to calibrate PCR input at unsaturated amplification for semiquantification. PCR products were electrophoresed on a $0.8 \%$ agarose gel and visualized by ethidium bromide staining. The gel images were stored with the use of the Gel Documentation System Image Store 7500, version 7.12 (UVP Inc, Upland, Calif) under an ultraviolet transilluminator. The average optical density of bands was quantitated by the GelBase/GelBlot-Pro Version 3.10 (Syngene/Synoptics Ltd, Frederick, Md).
Immunohistochemistry for hIL-10. Paraffin-embedded lung isograft sections were mounted on glass slides and permeabilized by incubation of the slides in Tris-buffered saline (TBS) solution (Tris, $100 \mathrm{mmol} / \mathrm{L} ; \mathrm{NaCl}, 500 \mathrm{mmol} / \mathrm{L} ; \mathrm{pH}$ 7.4) supplemented with $0.1 \%$ saponin and $0.2 \%$ Triton $\mathrm{X}-100$ octylphenoxypolyethoxyethanol (Union Carbide Corporation, Danbury, Conn) according to the protocol of R\&D Systems (Minneapolis, Minn) for cytokine localization. This buffer was used for all washings. After deparaffinization, slides were steam-treated in a citrate buffer target retrieval solution (DAKO Corporation, Carpenteria, Calif) for $35 \mathrm{~min}$ utes at $95^{\circ} \mathrm{C}$. After endogenous peroxidase was blocked with $3 \% \mathrm{H}_{2} \mathrm{O}_{2}$ /phosphate-buffered saline solution for 15 minutes, slides were incubated in SuperBlock blocking buffer (Pierce Chemical Company, Rockford, Ill) including 10\% normal goat serum and $1 \%$ bovine serum albumin. The immunohistochemistry procedure was performed with a tyramide signal amplification kit (TSA-Indirect; NEN Life Science Products, Boston, Mass), according to the manufacturer's instructions. In brief, after treatment with trinitrobenzene blocking buffer in TBS, the slides were incubated overnight at room temperature with $1: 25$, or 1:12.5-diluted biotinylated rat antiviral/hIL-10 monoclonal antibody (PharMingen, San Diego, Calif). After incubation with streptavidin-horseradish peroxidase for 30 minutes at room temperature, the slides were incubated in biotinyl tyramide solution for 15 minutes at room temperature. Then, these incubation steps with streptavidin-horseradish peroxidase and biotinyl tyramide solution were repeated. After subsequent washes in TBS/Triton X100 /saponin, the slides were incubated with streptavidinalkaline phosphatase for 30 minutes at room temperature. Color reaction was developed by a BCIP/NBT alkaline phosphatase substrate kit (Vector Laboratories, Inc, Burlingame, Calif) including a 5-mol/L concentration of levamisole. After about 8 minutes, the reaction field was blocked by washing in TE buffer (Tris, $10 \mathrm{mmol} / \mathrm{L} ; \mathrm{pH} 8.0$; ethylenediaminetetraacetic acid [EDTA], $1 \mathrm{mmol} / \mathrm{L})$, counterstained with nuclear fast red, and permanently mounted with Cytoseal 60 (Stephens Scientific, Kalamazoo, Mich).

Myeloperoxydase activity. Quantitative myeloperoxidase activity was determined as previously described. ${ }^{11}$ Although monocyte/macrophages have been shown to produce myeloperoxidase when activated, the monocyte/macrophage contribution to the total myeloperoxidase activity is far less than that of neutrophils because of quantitative predominance of neutrophils over monocyte/macrophages in peripheral blood and at sites of acute inflammation. Thus, myeloperoxidase activity reflects neutrophil sequestration into grafts. In brief, frozen lung samples were homogenized in $1 \mathrm{~mL}$ of $0.5 \%$ hexadecyltrimethyl-ammonium bromide, $5 \mathrm{mmol} / \mathrm{L}$ EDTA, and $50 \mathrm{mmol} / \mathrm{L}$ potassium phosphate buffer ( $\mathrm{pH}$ 6.2) with a Broeck tissue grinder (Kontes Glass Co, Vineland, NJ). Hexadecyltrimethyl-ammonium bromide is a detergent that releases myeloperoxidase from the primary granules of neutrophils. The homogenate was centrifuged at $10,000 \mathrm{~g}$ for 15 minutes at $4{ }^{\circ} \mathrm{C}$. The supernatant was subsequently assayed for total soluble protein by the method of Pierce Chemical 

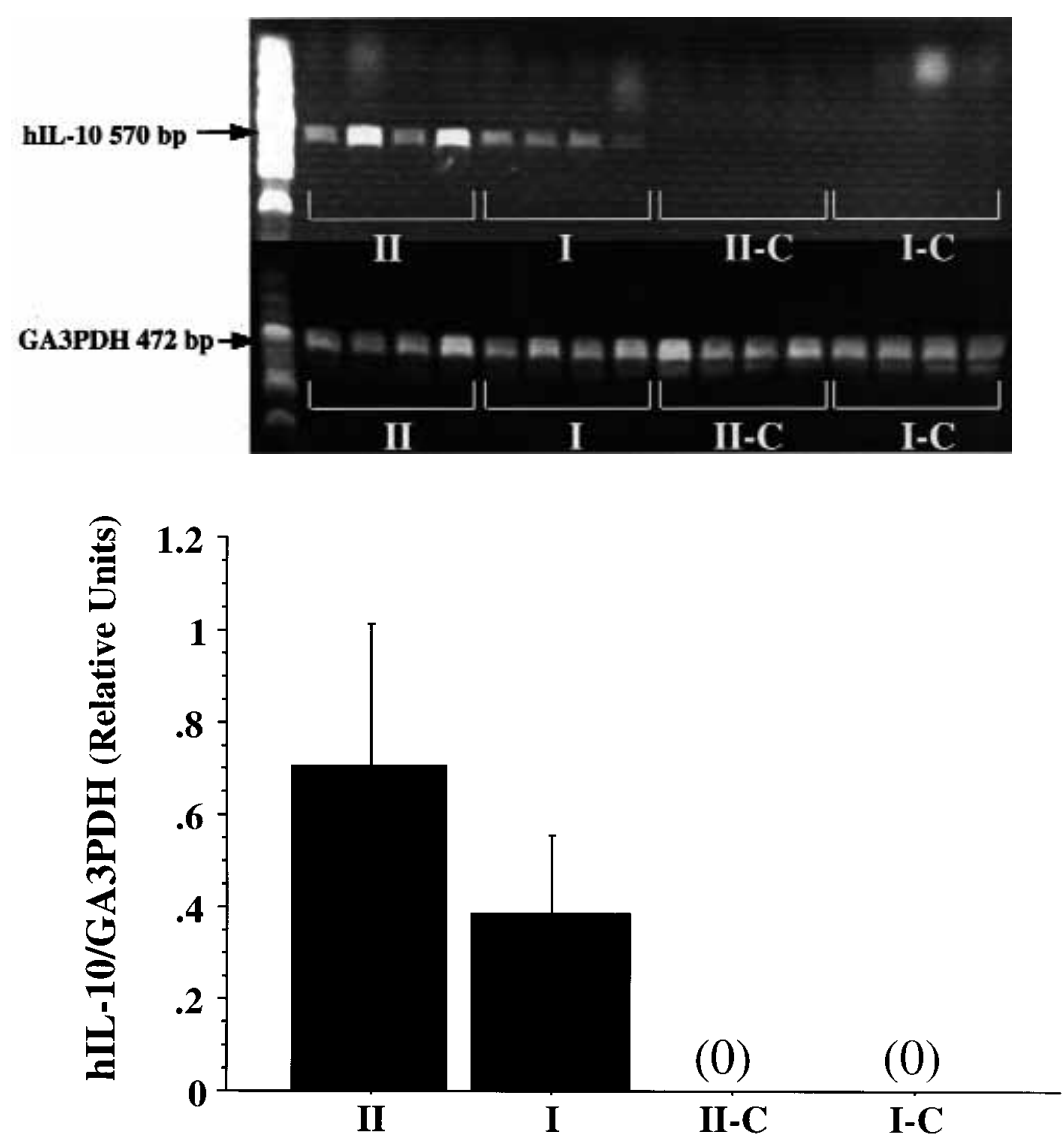

Fig 1. Semiquantitative RT-PCR analysis of transgene hIL-10 mRNA expression in rat lung isografts. Peak area of bands was expressed as a relative ratio of hIL-10/GA3PDH. The gel image shows $570 \mathrm{bp}$ hIL-10 bands in groups I and II, but not in groups I-C and II-C, showing 4 representatives from each group. Values are mean \pm SD of 4 to 6 animals per group.

Company (Rockford, Ill). ${ }^{12}$ Myeloperoxidase activity was measured spectrophotometrically as follows: $2 \mu \mathrm{L}$ of supernatant was combined with $0.6 \mathrm{~mL}$ Hanks bovine serum albumin $(0.25 \%$ bovine serum albumin added to Hanks solution), $0.5 \mathrm{~mL}$ of $100 \mathrm{mmol} / \mathrm{L}$ potassium phosphate buffer $(\mathrm{pH} \mathrm{6.2)}$, $0.1 \mathrm{~mL} 0.05 \% \mathrm{H}_{2} \mathrm{O}_{2}$, and $0.1 \mathrm{~mL}$ of $1.25 \mathrm{mg} / \mathrm{mL}$ o-dianisidine. Color development was stopped by the addition of 0.1 $\mathrm{mL}$ of $1 \% \mathrm{NaN}_{3}$ after 5 minutes and after 20 minutes at room temperature. Optical density was measured at $460 \mathrm{~nm}$ with a spectrophotometer (model PMQ II; Carl Zeiss, Jena, West Germany). Color development was linear from 5 to 20 minutes. One unit of enzyme activity was defined as the amount of 1.0 optical density unit per minute per microgram of tissue protein at room temperature. Myeloperoxidase activity of normal left lung of F344 rats $(\mathrm{NL}, \mathrm{n}=4)$ was also measured in the same way as the other groups for comparison.

Exhaled NO analysis. NO levels in isograft exhaled gas were measured by a Sievers 280 NO analyzer (Sievers Instruments, Inc, Boulder, Colo) within 30 minutes of collection. Emissions from electronically excited nitrogen dioxide were detected in a gas-phase chemiluminescent reaction between NO and ozone. The sensitivity of the measurement is less than $1 \mathrm{ppb}$. At every measurement, the baseline NO level of $100 \%$ oxygen was confirmed to be $0 \mathrm{ppb}$. Exhaled NO from normal left lung of F344 rats $(\mathrm{NL}, \mathrm{n}=4)$ was also measured in the same way as in the other groups.

Statistical analysis. Data were analyzed by 1-way analysis of variance (ANOVA) and the Fisher post hoc multiple comparison test. Data not normally distributed were transformed with a square root or logarithmic transformation before ANOVA was performed. All data are expressed as mean \pm standard deviation.

\section{Results}

Semiquantitative RT-PCR for transgene hIL-10. To confirm isograft AdRSVhIL-10 transfection at transcriptional levels, we performed semiquantitative RTPCR for transgene hIL-10. Expression of hIL-10 mRNA in lung grafts was detected in all samples of groups I and II, but not of groups I-C and II-C (Fig 1). These results confirmed hIL-10 gene transfection into 

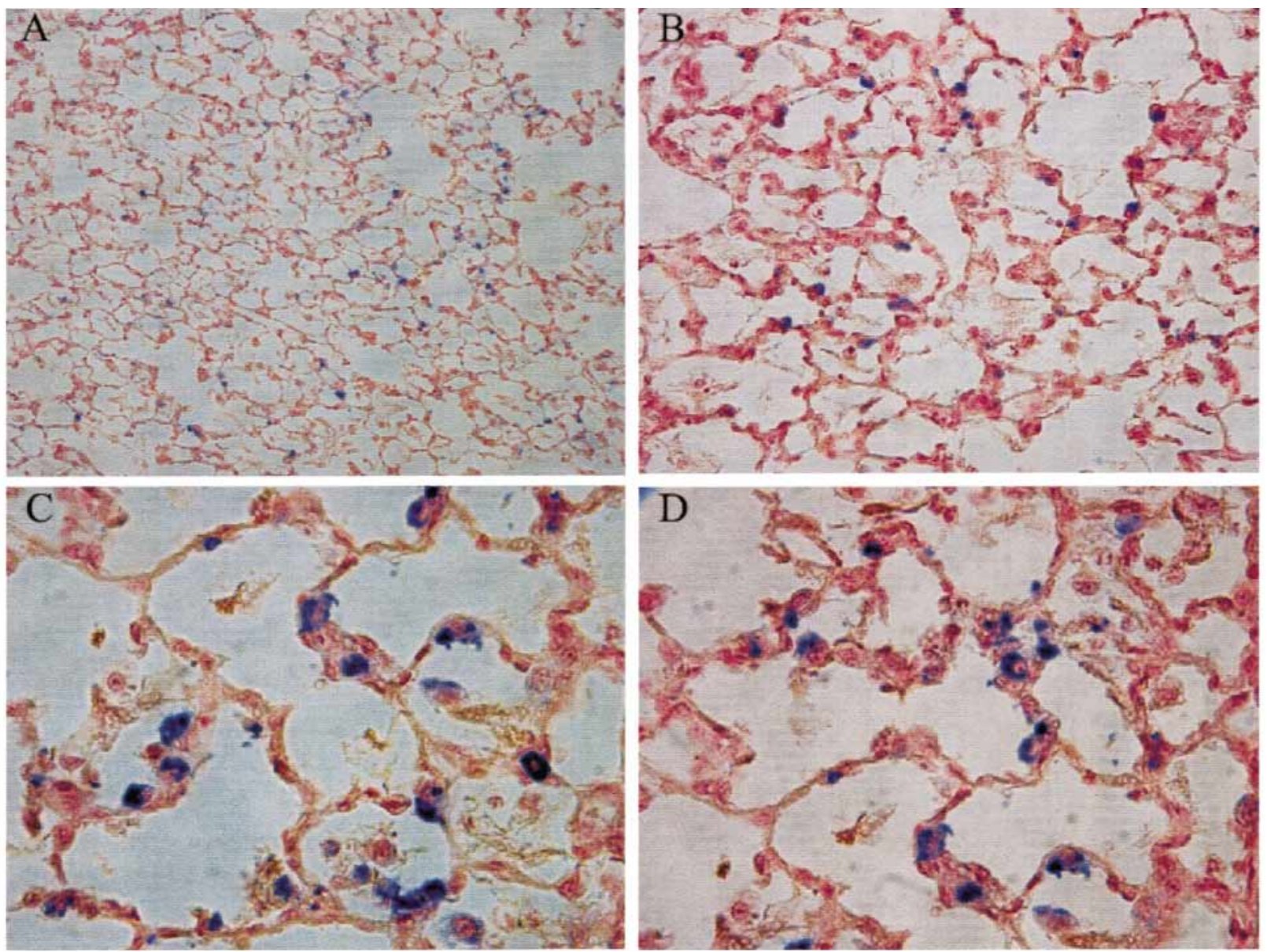

Fig 2. Immunohistochemistry for transgene hIL-10. Transgene hIL-10 protein was detected in the sections prepared from groups I and II as cytoplasmic staining in alveolar epithelial cells, mainly type II cells. There was no staining in capillary, large vessel endothelium, or airway epithelium. (Original magnifications: A, $\times 100 ; \mathbf{B}, \times 200 ; \mathbf{C}, \times 400$; D $\times 400$.)

lung isografts at transcriptional levels in groups I and II 2 days and 18 hours after transfection.

Immunohistochemistry for transgene hIL-10. To confirm isograft AdRSVhIL-10 transfection at translational levels in situ, we performed immunohistochemistry for transgene hIL-10 protein in sections from paraffin-embedded tissue. Alveolar epithelial cells, mainly type II cells in a scattered distribution, and fewer alveolar macrophages showed cytoplasmic staining (Fig 2). There was no staining in capillary, large vessel endothelium, or airway epithelial cells. Staining was specific to transgene hIL-10, since sections prepared from groups I-C and II-C and normal lungs (NL) were negative. These findings demonstrated hIL-10 transfection to specific types of lung cells and local production of hIL-10 transgene protein in isografts.
Lung graft function. To investigate the effects of graft hIL-10 overexpression on isograft lung function, we compared graft gas exchange and peak airway pressures among groups. Gas exchange remains the single most important parameter of lung function (Fig 3). Arterial $\mathrm{PO}_{2}$ (mean mm Hg $\pm \mathrm{SD}$ ) levels in arterial blood obtained 5 minutes after right hilar crossclamping in groups I $(164.72 \pm 85.3)$ and II $(153.19 \pm 113)$ were significantly higher than in groups I-C $(82.37 \pm 19.1)$ and II-C (77.95 \pm 33.4$)(P=.022$ and $P=.031$, respectively). Arterial $\mathrm{PCO}_{2}$ (mean $\mathrm{mm} \mathrm{Hg} \pm \mathrm{SD}$ ) levels in group I $(33.40 \pm 6.80)$ were significantly lower than in group I-C $(51.23 \pm 11.9)(P=.0096)$. There were no significant differences between groups in peak airway pressures $(P=.24)$. These data show that graft hIL-10 overexpression significantly improved graft lung function, suggesting the amelioration of graft I/R injury. 


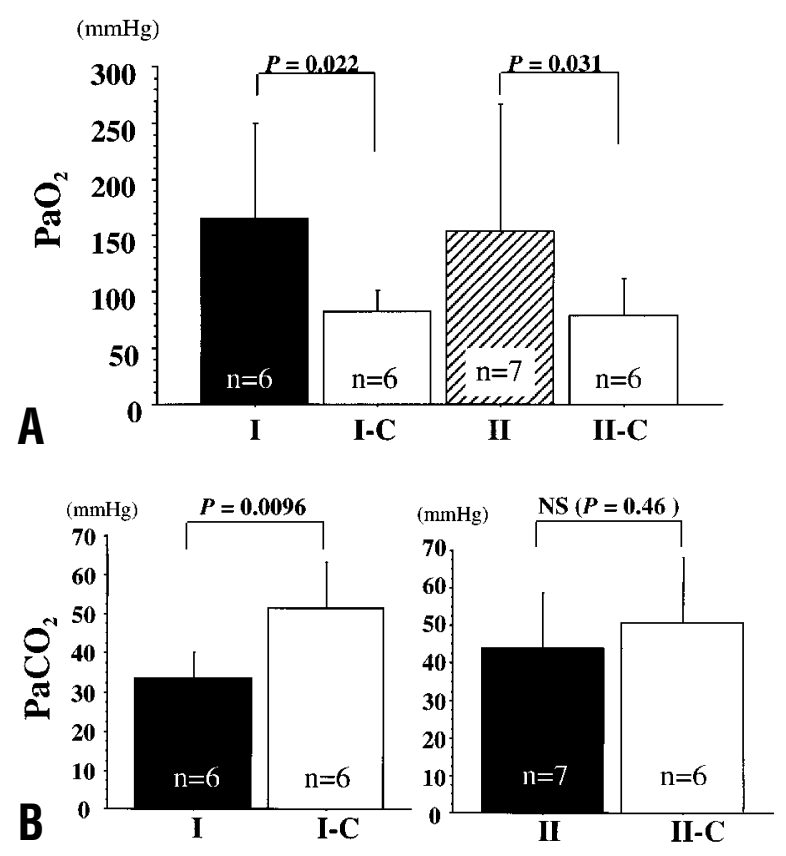

Fig 3. A, $\mathrm{PaO}_{2}$ of blood obtained 5 minutes after right hilar crossclamping. Each $\mathrm{PaO}_{2}$ in groups $\mathrm{I}(164.72 \pm 85.3 \mathrm{~mm} \mathrm{Hg})$ and II $(153.19 \pm 113 \mathrm{~mm} \mathrm{Hg})$ was significantly higher than in groups I-C $(82.37 \pm 19.1 \mathrm{~mm} \mathrm{Hg})$ and II-C $(77.95 \pm 33.4 \mathrm{~mm}$ $\mathrm{Hg})(P=.022$ and .031 , respectively, ANOVA $)$. Values are mean \pm SD of 6 to 7 animals per group. $\mathbf{B}, \mathrm{PaCO}_{2}$ of blood obtained 5 minutes after right hilar crossclamping. $\mathrm{PaCO}_{2}$ in group I $(33.40 \pm 6.80 \mathrm{~mm} \mathrm{Hg})$ was significantly lower than in group I-C $(51.23 \pm 11.9 \mathrm{~mm} \mathrm{Hg})(P=.0096$, ANOVA $)$. There were no significant differences between groups II (43.64 \pm $15.1 \mathrm{~mm} \mathrm{Hg})$ and II-C $(50.6 \pm 17.7 \mathrm{~mm} \mathrm{Hg})(P=.46$, ANOVA). Values are mean \pm SD of 6 to 7 animals per group.

Myeloperoxidase activity. To investigate hIL-10 effects on neutrophil sequestration into isografts, we compared myeloperoxidase activity levels among groups (Fig 4). Myeloperoxidase activity (mean OD . $\left.\mathrm{min}^{-1} \cdot \mathrm{mg}^{-1} \pm \mathrm{SD}\right)$ in group II $(0.083 \pm 0.031)$ was significantly lower than in group II-C $(0.117 \pm 0.028)$ $(P=.044)$. There were no significant differences between group I $(0.124 \pm 0.061)$ and group I-C $(0.086$ $\pm 0.034)(P=.16)$. Myeloperoxidase activity in normal lungs (NL) $(0.046 \pm 0.013)$ was significantly lower than in group I, II, or II-C $(P<.05$, respectively). These results suggest that $\mathrm{I} / \mathrm{R}$ causes significant neutrophil sequestration into lung grafts and that hIL-10 overexpression reduced this sequestration, ameliorating subsequent neutrophil-mediated lung injury.

Semiquantitative RT-PCR for graft cytokine mRNA expression. To investigate the effects of graft hIL-10 overexpression on isograft cytokine mRNA
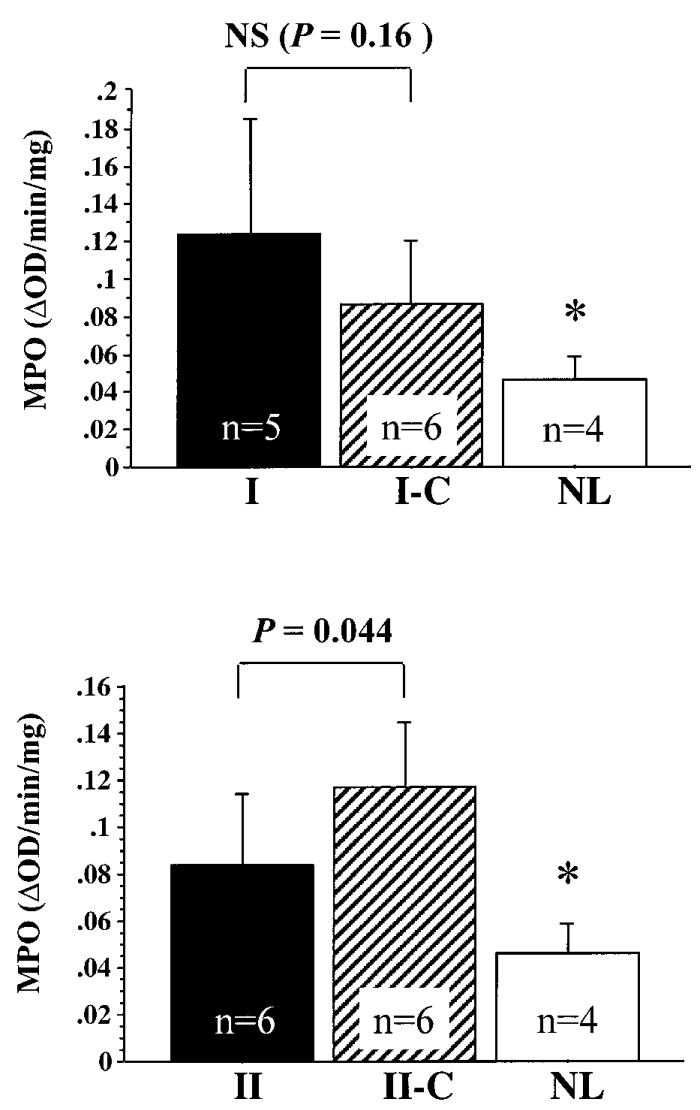

Fig 4. Myeloperoxidase (MPO) activity in rat lung isografts. Myeloperoxidase activity in group II $(0.083 \pm 0.031 \mathrm{OD}$. $\left.\mathrm{min}^{-1} \cdot \mathrm{mg}^{-1}\right)$ was significantly lower than in group II-C $\left(0.117 \pm 0.028 \mathrm{OD} \cdot \mathrm{min}^{-1} \cdot \mathrm{mg}^{-1}\right)(P=.044$, ANOVA $)$. There were no significant differences between groups I $(0.124 \pm$ $\left.0.061 \mathrm{OD} \cdot \mathrm{min}^{-1} \cdot \mathrm{mg}^{-1}\right)$ and I-C $\left(0.086 \pm 0.034 \mathrm{OD} \cdot \mathrm{min}^{-1}\right.$ $\left.\cdot \mathrm{mg}^{-1}\right)(P=.16$, ANOVA). Values are mean \pm SD of 4 to 6 animals per group. Myeloperoxidase activity in normal lung $(N L)$ was significantly lower than groups I, II, and II-C $(* P<$ .05 , respectively, ANOVA).

expression at 24 hours of reperfusion, we performed semiquantitative RT-PCR for graft cytokine mRNA expression. Levels of iNOS expression (mean relative units $\pm \mathrm{SD})$ in lung grafts in group II $(0.627 \pm 0.28)$ were significantly lower than in group II-C $(1.125 \pm 0.63)$ $(P=.039)$, whereas normal lung (NL) iNOS expression $(0.097 \pm 0.11)$ was significantly lower than in all other groups $(P<.05$, respectively) (Fig 5). There were no significant differences between groups I $(0.455 \pm 0.42)$ and I-C $(0.755 \pm 0.29)(P=.13)$, indicating that iNOS mRNA expression level was minimal in normal lung and up-regulated in graft I/R injury by 24 hours after reperfusion. The iNOS mRNA up-regulation was significant- 

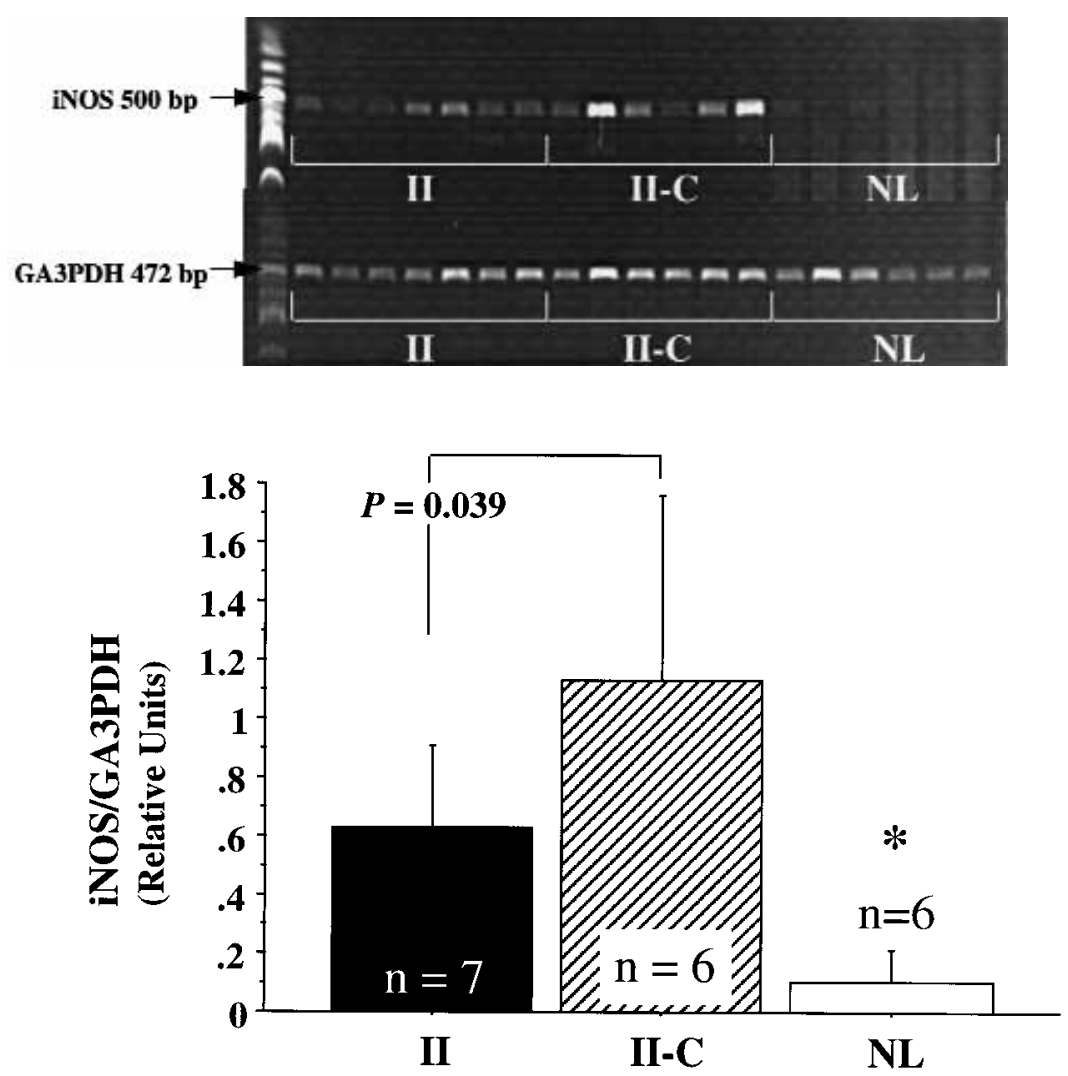

Fig 5. Semiquantitative RT-PCR analysis of iNOS mRNA expression in rat lung isografts. Peak area of bands was expressed as relative ratio of iNOS/GA3PDH. iNOS mRNA expression in group II $(0.627 \pm 0.28)$ was significantly lower than group II-C $(1.125 \pm 0.63)(P=.039$, ANOVA). iNOS mRNA expression in normal lung $(N L)(0.097$ $\pm 0.11)$ was significantly lower than other groups $(* P<.05$, respectively, ANOVA). Values are mean \pm SD of 6 to 7 animals per group.

ly suppressed only by high amounts of graft hIL-10 transfection. Normal lung mRNA expression of TNF- $\alpha$ and monocyte chemotactic protein-1 was significantly lower than in all other groups $(P<.05$, respectively), although there were no significant differences between groups I and I-C or groups II and II-C. There were no significant differences among groups in GRO/CINC-1 and ICAM-1 mRNA expression levels $(P=.33$ and $P=.31$, respectively) (Fig 6).

Exhaled NO levels. To investigate hIL-10 effects on exhaled NO levels of isografts, we compared exhaled NO levels at 24 hours of reperfusion between groups. There were no significant differences between groups in exhaled NO levels $(P=.25)$; exhaled NO levels (mean ppb $\pm \mathrm{SD})$ in groups I $(6.525 \pm 6.61)$, I-C (3.133 $\pm 4.01)$, II $(6.357 \pm 5.93)$, II-C (3.033 \pm 4.60$)$, and normal left lungs (NL) of F344 rats $(0.00 \pm 0.0)$ are given in Fig 7.

\section{Comment}

The present data show that overexpression of hIL-10 in lung isografts by means of donor in vivo adenovirusmediated gene transfer improved gas exchange, reduced lung neutrophil sequestration, and down-regulated local iNOS mRNA expression 24 hours after graft reperfusion. During the initial phase of lung I/R injury, pulmonary resident macrophages are activated and release reactive oxygen species and pro-inflammatory cytokines, including TNF- $\alpha$ and IL- $1 .{ }^{13}$ The enhanced production of TNF- $\alpha$ and IL- 1 plays a central role in the initiation of a cascade of events including the recruitment of neutrophils that causes significant lung graft injury. One of the main functions of TNF- $\alpha$ and IL-1 is the up-regulation of adhesion molecules ${ }^{14}$ and neutrophil-attracting CXC chemokines. ${ }^{15}$ The coordinated efforts of adhesion molecules and CXC chemokines mediate the recruitment of neutrophils into 

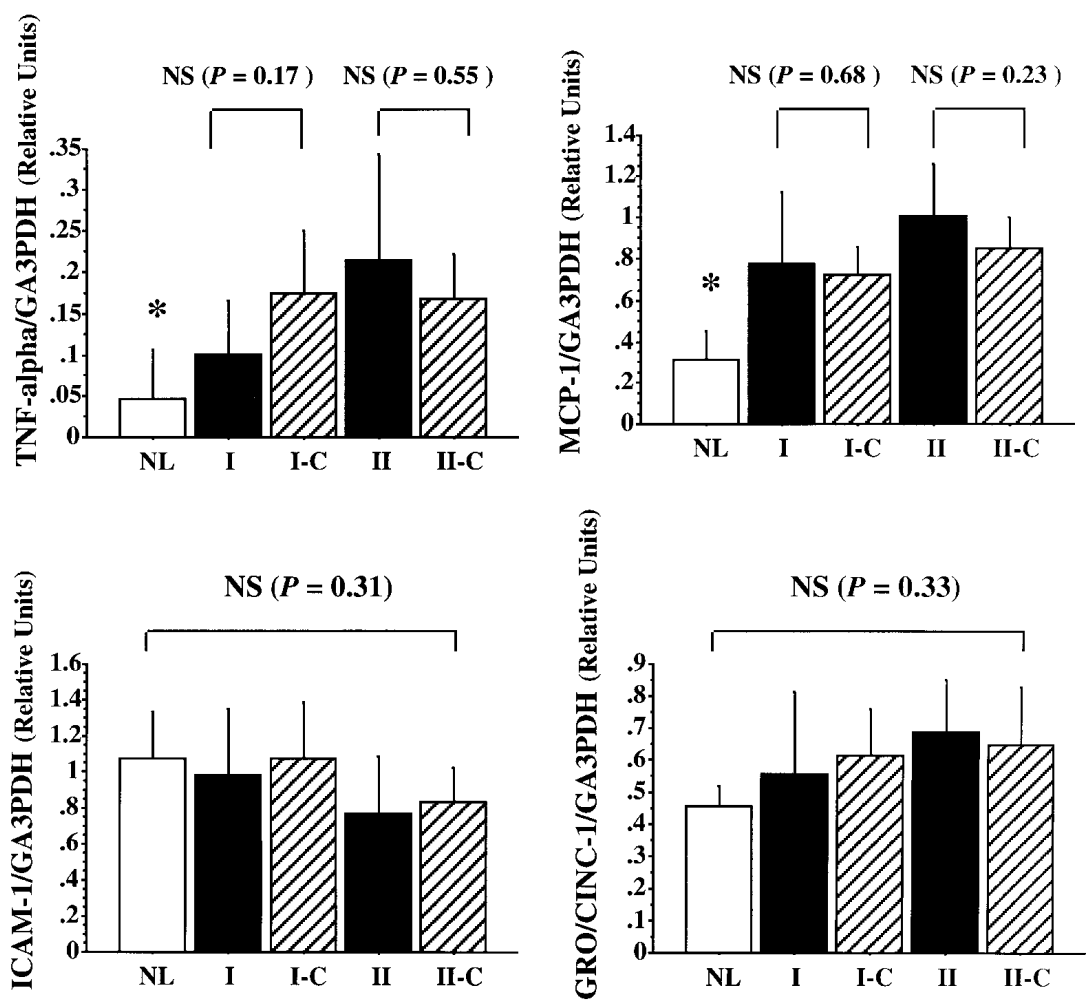

Fig 6. Semiquantitative RT-PCR analysis for mRNA expression of TNF- $\alpha$, monocyte chemotactic protein-1 $(M C P-1)$, ICAM-1, and GRO/CINC-1 in rat lung isografts. Normal lung $(N L)$ mRNA expression in TNF- $\alpha$ and monocyte chemotactic protein- 1 were significantly lower than other groups $(* P<.05$, respectively, ANOVA). There were no significant differences between groups in ICAM-1 and GRO/CINC-1. Values are mean \pm SD of 4 to 7 animals per group.

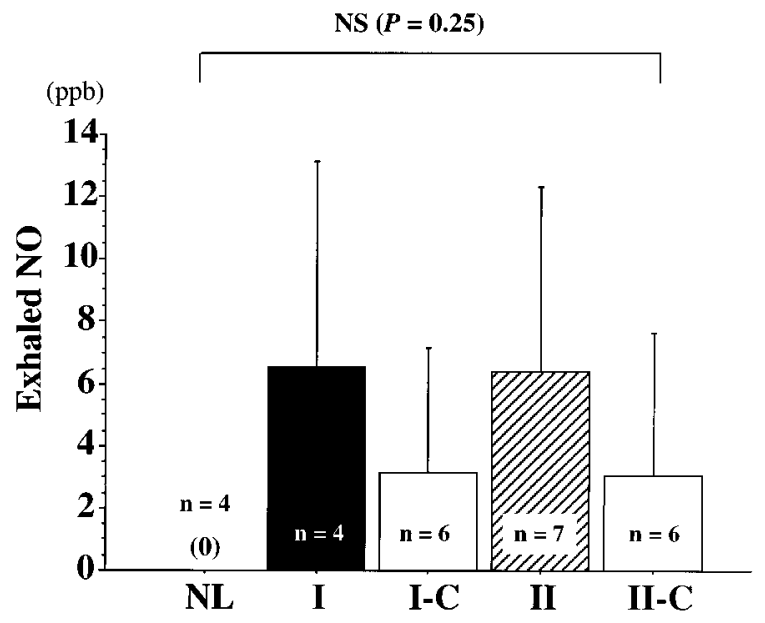

Fig 7. Exhaled NO levels (ppb) from rat lung isografts. There were no significant differences between groups $(P=$ .25 , ANOVA). Values are mean \pm SD of 4 to 7 animals per group. lung grafts. Sequestrated, activated neutrophils may be one of the primary effector cells that mediate acute lung graft injury through the release of a variety of inflammatory mediators, including proteolytic enzymes and reactive oxygen species. According to various in vitro studies, IL-10 can suppress macrophage function with the production of TNF- $\alpha$, IL- $1,{ }^{2,3}$ several chemokines, ICAM- $1,{ }^{16}$ and superoxide anion, ${ }^{5}$ which are closely involved in organ $\mathrm{I} / \mathrm{R}$ injury. It has been also reported that IL-10 inhibits neutrophil function, including cytokine/chemokine production ${ }^{10}$ and the generation of free radicals. ${ }^{17}$ Recent in vivo studies have also suggested a protective role for $\mathrm{IL}-10$ during lung $\mathrm{I} / \mathrm{R}$ injury in the rat, ${ }^{18}$ intestinal I/R injury in the mouse, ${ }^{19}$ or immune complex-induced lung injury in the rat. ${ }^{20}$ Consistent with these reports, the present results showed that IL-10 overexpression ameliorates I/R injury, suggesting a cumulative effect of its various anti-inflammatory functions at crucial steps of the above-mentioned lung I/R injury cascade. 
The present results showed that graft overexpression of hIL-10 suppresses local iNOS expression, with simultaneous attenuation of the net isograft I/R injury. Several reports of iNOS suppression by IL- $10^{6}$ support these results. Although NO is thought to play a crucial role in lung I/R injury, its net effect on lung I/R injury remains unclear, depending on the fine balance between its toxicity on one hand and its salutary action on the other. In a canine lung transplant model, nitroprusside (NO donor) significantly improved gas exchange and prevented neutrophil sequestration in lungs. ${ }^{21}$ NO inhalation has been also advocated as a means of selectively reducing pulmonary hypertension and improving ventilation/perfusion mismatching in patients with adult respiratory distress syndrome. ${ }^{22} \mathrm{NO}$ has been shown to cause smooth muscle relaxation (by activating soluble guanylate cyclase) and to inhibit platelet aggregation and adhesion to the endothelium (by increasing cyclic guanosine monophosphate). The potential role of $\mathrm{NO}$ as a cytotoxic effector molecule may, on the other hand, contribute to lung I/R injury through inactivation of critical iron-containing enzymes, such as complexes I and II of the respiratory chain $^{23}$ or a radical-radical reaction with superoxide to yield peroxynitrite anion $\left(\mathrm{ONOO}^{-}\right)$, a potent oxidizing cytotoxic molecule. ${ }^{24}$ It has been shown that NO synthase inhibitors caused the limited neutrophil accumulation and vascular protein leakage in postischemic lung and skeletal muscle in rats. ${ }^{25}$ Noiri and associates ${ }^{26}$ have also shown that targeted inhibition of iNOS with antisense oligodeoxynucleotide attenuated ischemia-induced renal dysfunction in rats. Put into the context of these studies, our data imply that lung graft $\mathrm{I} / \mathrm{R}$ injury is at least partially mediated by up-regulation of iNOS. IL-10 may attenuate lung I/R injury by suppressing NO-driven injury. The precise relationship between lung I/R injury and NO is not yet clear.

In the present study, adenovirus vectors were intravenously administered to donors 24 hours before harvest. Serotype 2 and 5 recombinant adenovirus vectors are trophic to the respiratory tract and have been the most widely used vectors for gene transfer to the lung. Several in vivo studies have demonstrated its biodistribution, clearance, or time-course of transgene expression after intravenous administration. Intravenous administration of the adenovirus vectors delivers the vast majority of the input virus to the liver. ${ }^{27}$ More than $90 \%$ of the administered vector is also eliminated from the body within 24 hours of administration, well before maximal levels of transgene are expressed. ${ }^{28}$ Only a small percentage of the input adenovirus vector, therefore, is responsible for subsequent transgene expression found in lungs. One study reported that gene expression after intratracheal AdRSVLacZ transfection peaked on day 5 and was sustained over a 21- to 28-day period. ${ }^{29}$ This pattern of transgene expression seems suitable for achieving adenovirus hIL-10 transgene expression at the time of isograft reperfusion with the present incubation and storage time. Using AdHSP-70, $\mathrm{we}^{30}$ have previously shown that the same dose and timing of adenovirus administration and harvest/preservation produced transgene expression at reperfusion and decreased reperfusion injury.

In this experiment, immunohistochemistry for transgene hIL-10 demonstrated predominant cytoplasmic staining of alveolar epithelial cells, mainly type II cells. Several studies of acute wild-type adenoviral respiratory infection have shown that there is a histologic pattern with predominant involvement of pneumocytes over other bronchial epithelial cells. ${ }^{31}$ When adenovirus enters into the cells, several variables potentially can play a role in the cell-type affinity of adenovirus vectors; that is, densities of fiber knob receptor and integrins on the cell surface, differential rate of endocytosis, and electrostatic repulsion by the negative charge of both adenovirus and cells. ${ }^{32}$ Taken together, it is conceivable that type II alveolar epithelial cells have relatively more affinity to adenovirus vectors than endothelial or bronchial epithelial cells. This is consistent with the present immunohistochemistry result.

Although we have previously demonstrated a positive correlation between iNOS mRNA expression and exhaled NO levels in a rat lung allograft rejection model, increased iNOS mRNA levels in lung isografts at 24 hours of reperfusion did not correlate positively to exhaled NO levels in the current study. There has been one report demonstrating that the exhaled NO levels were acutely up-regulated and returned to baseline over several minutes after hydrochloric acid-induced canine lung injury. ${ }^{33}$ In this report, increased nitrite/nitrate levels in the bronchoalveolar lavage fluid 4 hours after lung injury suggested that iNOS and NO are up-regulated but cannot be reflected by exhaled NO levels. It is possible that massive alveolar exudate in the severely injured lung grafts, as is in our present study, played a role like a sink for NO preventing its measurement by the exhaled route.

In conclusion, the present study demonstrated that overexpression of hIL-10 in lung isografts by means of donor in vivo adenovirus-mediated gene transfer ameliorates I/R injury, causing improved gas exchange, reduced lung neutrophil sequestration, and down-regulation of local iNOS mRNA expression. These results suggest the therapeutic potential of graft IL-10 gene transfer as an effective strategy against acute graft dysfunction after lung transplantation. 
We thank Richard B. Schuessler, PhD, for the statistical consultation, Paul J. Goodfellow, $\mathrm{PhD}$, for assistance with gel image processing, Kathleen Grapperhaus, for experimental setup, and Dawn Schuessler and Mary Ann Kelly for secretarial assistance.

\section{REFERENCES}

1. Meyers BF, Lynch J, Trulock EP, Guthrie TJ, Cooper JD, Patterson GA. Lung transplantation: a decade of experience. Ann Surg 1999;230:362-70.

2. de Waal Malefyt R, Abrams J, Bennet B, Figdor CG, de Vries JE. Interleukin-10 (IL- 10) inhibits cytokine synthesis by human monocytes: an autoregulatory role of IL-10 produced by monocytes. J Exp Med 1991;174:1209-20.

3. Fioirentino DF, Zlotnik A, Vieira P, Mosmann TR, Howard M, Moore KW, et al. IL-10 acts on the antigen-presenting cell to inhibit cytokine production by Th1 cells. J Immunol 1991;146:3444-51.

4. Hart PH, Hunt EK, Bonder CS, Watson CJ, Finlay-Jones JJ. Regulation of surface and soluble TNF receptor expression on human monocytes and synovial fluid macrophages by IL-4 and IL-10. J Immunol 1996;157:3672-80.

5. Kuga S, Otsuka T, Niiro H, Nunoi H, Nemoto Y, Nakano T, et al. Suppression of superoxide anion production by interleukin-10 is accompanied by down regulation of the genes for subunit proteins of NADPH oxidase. Exp Hematol 1996;24:151-7.

6. Cunha FQ, Moncada S, Liew FY. Interleukin-10 (IL-10) inhibits the induction of nitric oxide synthase by interferon-gamma in murine macrophages. Biochem Biophys Res Com 1992;182: 1155-9.

7. Lehrach D, Diamond D, Wozney J, Boedtker H. RNA molecular weight determinations by gel electrophoresis under denaturing conditions: a critical reexamination. Biochemistry 1977; 16:4743-51.

8. Gudmundsson G, Bosch A, Davidson BL, Berg DJ, Hunninghake GW. Interleukin-10 modulates the severity of hypersensitivity pneumonitis in mice. Am J Respir Cell Mol Biol 1998;19:812-8.

9. Mizuta T, Kawaguchi A, Nakahara K, Kawashima Y. Simplified rat lung transplantation using a cuff technique. J Thorac Cardiovasc Surg 1989;97:578-1.

10. Kasama T, Strieter RM, Lukacs NW, Burdick MD, Kunkel SL. Regulation of neutrophil-derived chemokine expression by IL-10. J Immunol 1994;152:3559-69.

11. Krawisz JE, Sharon P, Stenson WF. Quantitative assay for acute intestinal inflammation based on myeloperoxidase activity: assessment of inflammation in rat and hamster models. Gastroenterology 1984;87:1344-50.

12. Smith PK, Krohn RI, Hermanson GT, Mallia AK, Gartner FH, Provenzano MD, et al. Measurement of protein using bicinchoninic acid. Anal Biochem 1985;150:76-85.

13. Eppinger MJ, Deeb GM, Bolling SF, Ward PA. Mediators of ischemia-reperfusion injury of rat lung. Am $\mathrm{J}$ Pathol 1997;150:1773-84.

14. Mulligan MS, Vaporciyan AA, Miyasaka M, Tamatani T, Ward PA. Tumor necrosis factor alpha regulates in vivo intrapulmonary expression of ICAM-1. Am J Pathol 1993;142:1739-49.

15. Colletti LM, Kunkel SL, Walz A, Burdick MD, Kunkel RG, Wilke CA, et al. Chemokine expression during hepatic ischemia/reperfusion-induced injury in the rat: the role of epithelial neutrophil activating protein. J Clin Invest 1995;95:134-41.

16. Song S, Ling-Hu H, Roebuck KA, Rabbi MF, Donnelly RP, Finnegan A. Interleukin-10 inhibits Interferon-gamma-induced intercellular adhesion molecule-1 gene transcription in human monocytes. Blood 1997;89:4461-9.

17. Chaves MM, Silverstrini AA, Silva-Teixeira DN, NogueiraMachado JA. Effect in vitro of gamma interferon and interleukin10 on generation of oxidizing species by human granulocytes. Inflamm Res 1996;45:313-5.

18. Eppinger MJ, Ward PA, Bolling SF, Deeb GM. Regulatory effects of interleukin-10 on lung ischemia-reperfusion injury. J Thorac Cardiovasc Surg 1996;112:1301-6.

19. Lane JS, Todd KE, Lewis MP, Gloor B, Ashley SW, Reber HA, et al. Interleukin-10 reduces the systemic inflammatory response in a murine model of intestinal ischemia/reperfusion. Surgery 1997;122:288-94

20. Mulligan MS, Jones ML, Vaprociyan AA, Howard MC, Ward PA. Protective effects of IL-4 and IL-10 against immune complexinduced lung injury. J Immunol 1993;151:5666-74.

21. Fujino S, Nagahiro I, Yamashita M, Yano M, Schmid RA, Cooper JD, et al. Preharvest nitroprusside flush improves posttransplantation lung function. J Heart Lung Transplant 1997;16:1073-80.

22. Chollet-Martin S, Gatecel C, Kermarrec N, Gougerot-Pocidalo MA, Payen DM. Alveolar neutrophil functions and cytokine levels in patients with the adult respiratory distress syndrome during nitric oxide inhalation. Am J Respir Crit Care Med 1996;153:985-90.

23. Al-Ali MK, Howarth PH. Nitric oxide and the respiratory system in health and disease. Respir Med 1998;92:701-15.

24. Beckman JS, Beckman TW, Chen J, Marshall PA, Freeman BA. Apparent hydroxyl radical production by peroxynitrite: implications for endothelial injury from nitric oxide and superoxide. Proc Natl Acad Sci U S A 1990;87:1620-4.

25. Seekamp A, Mulligan MS, Till GO, Ward PA. Requirements for neutrophil products and 1-arginine in ischemia-reperfusion injury. Am J Pathol 1993;142:1217-26.

26. Noiri E, Peresleni T, Miller F, Goligorsky MS. In vivo targeting of inducible NO synthase with oligodeoxynucleotides protects rat kidney against ischemia. J Clin Invest 1996;97:2377-83.

27. Zinn KR, Douglas JT, Smyth CA, Liu HG, Wu Q, Krasnykh VN, et al. Imaging and tissue biodistribution of $99 \mathrm{mTc}$-labeled adenovirus knob (serotype 5). Gene Ther 1998;5:798-808.

28. Worgall S, Wolff G, Falck-Pedersen E, Crystal RG. Innate immune mechanism dominate elimination of adenoviral vectors following in vivo administration. Hum Gene Ther 1997;8:37-44.

29. Champion HC, Bivalacqua TJ, D'Souza FM, Ortiz LA, Jeter JR, Toyoda K, et al. Gene transfer of endothelial nitric oxide synthase to the lung of the mouse in vivo: effect on agonistinduced and flow-mediated vascular responses. Circ Res 1999;84:1422-32.

30. Hiratsuka M, Mora BN, Yano M, Mohanakumar T, Patterson GA Gene transfer of heat shock protein 70 protects lung grafts from ischemia-reperfusion injury. Ann Thorac Surg 1999;67:1421-7.

31. Rosman FC, Mistchenko AS, Ladenheim HS, do Nascimento JP, Outani HN, Madi K, et al. Acute and chronic human adenovirus pneumonia: cellular and extracellular matrix components. Pediatr Pathol Lab Med 1996;16:521-41.

32. Kaplan JM, Pennington SE, St. George JA, Woodworth LA, Fasbender A, Marshall J, et al. Potentiation of gene transfer to the mouse lung by complexes of adenovirus vector and polycations improves therapeutic potential. Hum Gene Ther 1998;9:1469-79.

33. Lee KH, Rico P, Billiar TR, Pinsky MR Nitric oxide production after acute, unilateral hydrochloric acid-induced lung injury in a canine model. Crit Care Med 1998;26:2042-7. 